\begin{tabular}{|l|c|c|c|r|}
\hline $\begin{array}{l}\text { Cuadernos de Investigación Geográfica } \\
\text { Geographical Research Letters }\end{array}$ & 2017 & N $^{\circ} 43(2)$ & pp. 571-590 & $\begin{array}{r}\text { ISSN 0211-6820 } \\
\text { eISSN 1697-9540 }\end{array}$ \\
\hline
\end{tabular}

DOI: http://doi.org/10.18172/cig.3202

(C) Universidad de La Rioja

\title{
PLEISTOCENE GLACIATIONS IN THE NORTHERN TROPICAL ANDES, SOUTH AMERICA (VENEZUELA, COLOMBIA AND ECUADOR)
}

\author{
I. ANGEL ${ }^{*}$, O. GUZMÁN ${ }^{1}$, J. CARCAILLET ${ }^{2}$ \\ ${ }^{1}$ Departamento de Ciencias de la Tierra, Universidad Simón Bolívar, \\ 89000, Caracas 1081-A, Venezuela. \\ ${ }^{2}$ ISTerre, Université de Grenoble 1, UMR CNRS 5275, F-38041 Grenoble, France.
}

\begin{abstract}
This article presents an overview of glaciation studies in the northern tropical Andes (Venezuela, Colombia and Ecuador) mostly based on glacial geochronological data. The oldest dated evidences of glaciations are recorded in the Colombian Andes at the Bogotá Plain between 3000-3500 m a.s.l., dated between 1-3 Ma. Maximum extent of former glaciers in the northern Andes seems to have occurred prior to the global Last Glacial Maximum (gLGM). In the Venezuelan-Mérida Andes, former glaciers mostly reached the lowest recorded elevations during MIS 5-MIS 4, whereas in the Colombian Andes, the maximum extents are recorded prior to $38 \mathrm{ka}$. In the Ecuadorian Andes the most extensive glacial cover probably occurred during MIS 8. In the northern tropical Andes, studied glacier advances are mainly related to MIS 2 period between the final gLGM to the Oldest Dryas ( 18 ka-15 ka). Glacier advances during the Younger Dryas ( $12.7 \mathrm{ka}-11.7 \mathrm{ka})$ are not extensively evidenced and mainly restricted to elevations higher than $\sim 3500 \mathrm{~m}$ a.s.l.
\end{abstract}

Glaciaciones pleistocenas en el norte de los Andes Tropicales, Sudamérica (Venezuela, Colombia y Ecuador)

RESUMEN. El presente artículo es una revisión sobre el conocimiento de las glaciaciones en el norte de los Andes tropicales. Los estudios utilizados en el presente artículo son principalmente aquellos que cuentan con un buen apoyo de cronología glacial. Las evidencias más antiguas de la actividad glaciar en los Andes tropicales se han encontrado en los Andes Colombianos, específicamente en la Llanura de Bogotá entre los 3000-3500 m s.n.m., con edades entre 1 y 3 Ma. Con respecto a la máxima extensión de los glaciares en los Andes tropicales, parece haber ocurrido en edades previas al Último Máximo Glaciar(UMG). En los Andes Venezolanos la máxima extensión hasta ahora registrada ocurrió durante el MIS 5 y el MIS 4, mientras que en los Andes Colombianos ocurrió hace más de $38 \mathrm{ka}$. En los Andes Ecuatorianos la máxima extensión de los glaciares ocurrió probablemente durante el MIS 8. La mayoría de los avances glaciares en los Andes 
tropicales están relacionados con el MIS 2, y más concretamente con el período comprendido entre el final del UMG y el Oldest Dryas (OtD) ( 18 ka-15 ka). En el norte de los Andes tropicales han sido encontradas pocas evidencias de avances glaciares durante el Younger Dryas, y se hallan generalmente restringidas a elevaciones por encima de $\sim 3500 \mathrm{~m}$ a.s.l.

Keywords: Glaciations of the tropical Andes, TCN, radiocarbon dating, glacial landforms, Colombian Andes, Venezuelan Andes, Ecuadorian Andes, Pleistocene, Late Glacial, Last Glacial Maximum, Younger Dryas.

Palabras clave: Glaciaciones de los Andes tropicales, TCN, datación por radiocarbono, formas glaciares, Andes colombianos, Andes venezolanos, Andes ecuatorianos, Pleistoceno, Tardiglacial, Último Máximo Glaciar, Younger Dryas.

Received: 15 December 2016 Accepted: 2 March 2017

* Corresponding author: Isandra Angel. Departamento de Ciencias de la Tierra, Universidad Simón Bolívar, 89000, Caracas 1081-A, Venezuela. E-mail address: iangel_ceballos@ yahoo.com

\section{Introduction}

The Andean Cordillera is located along the west of South America. The Cordillera can be divided into northern (most peaks $<5000 \mathrm{~m}$ a.s.1.), central ( $<7000 \mathrm{~m}$ a.s.1.), and southern (<2000 m a.s.1.) regions based on structural characteristics (Clapperton, 1993). The tropical Andes are located in the northern and central Cordillera $\left(\sim 10^{\circ} \mathrm{N}-23^{\circ} \mathrm{S}\right)$. The central tropical Andes have been extensively studied to reconstruct glacial extent and associated timing (e.g. Coronato and Rabassa, 2007; Smith et al., 2008; Rodbell et al., 2009; Jomelli et al., 2009). However, glaciations knowledge in the northern tropical Andes is limited. The northern tropical Andes are located between $11^{\circ} \mathrm{N}-4^{\circ} \mathrm{S}$ including the Venezuelan, Colombian and Ecuadorian Andes. Glacial chronologies from the northern tropical Andes can vastly improve our knowledge about tropical glaciations and the relations between tropical and global climate systems.

The Venezuelan Andes consist of two northeast to southwest trending cordilleras named Sierra de Perijá and the Mérida Andes between $11^{\circ} \mathrm{N}-7^{\circ} \mathrm{N}$ (Schubert, 1979; Schubert and Vivas, 1993) (Fig. 1). Studies developed in the Mérida Andes have supported the knowledge on glaciations in the Venezuelan Andes; evidences of glaciations in the Sierra de Perijá have not been reported. In the Mérida Andes glaciers and glaciations studies have been developed from late 19th and beginning of the 20th centuries (e.g. Sievers, 1885; Jahn, 1925). The area occupied by glaciers during the Last Glacial Maximum (LGM) was around $200 \mathrm{~km}^{2}$ (Schubert and Clapperton, 1990) and currently glaciers area is reduced to $0.017 \mathrm{~km}^{2}$ (Braun and Bezada, 2013). Glaciation studies in the Venezuelan Andes are based on glaciofluvial, glaciolacustrine, glacial sediments and paleosol analysis mainly using radiocarbon dating (e.g. Rull, 1998; Mahaney et al., 
2001; Dirszowsky et al., 2005; Stansell et al., 2005; Mahaney et al., 2007; Carrillo et al., 2008; Kalm and Mahaney, 2011). However, more recently contributions based on Terrestrial Cosmogenic Nuclide dating (TCN), specifically ${ }^{10} \mathrm{Be}$ of moraine boulders and roches moutonnées are available (Wesnousky et al., 2012; Angel et al., 2013; Carcaillet et al., 2013; Guzmán, 2013; Angel, 2016; Angel et al., 2016).

The Colombian Andes are located between $11^{\circ} \mathrm{N}-1^{\circ} \mathrm{N}$ and are constituted by the Cordilleras Occidental (Western), Central and Oriental (Eastern) (Fig. 1). The area covered by Pleistocene glaciers was approximately $26,000 \mathrm{~km}^{2}$ (Thouret et al., 1996), whereas toward the end of the $20^{\text {th }}$ century it was around $104 \mathrm{~km}^{2}$ (Hoyos-Patiño, 1998). In the Colombian Andes, glaciation studies have been principally developed in the Eastern and Central Cordillera, and these studies are mainly based on radiocarbon dating of paleosols, glaciofluvial and other glacial sediments (e.g. van der Hammen et al., 1973; 1980; 19981; Helmens, 1988; 1996; 1997; 2004; 2011; Clapperton, 2000; Thouret et al., 1996).

The Ecuadorian Andes are located between $1^{\circ} \mathrm{N}-4^{\circ} \mathrm{S}$ and are constituted by the Eastern and Western Cordilleras (Fig. 1). Glaciation studies are mainly based on radiocarbon dating of glaciolacustrine and till sediments (e.g. Seltzer et al., 1995; Clapperton et al., 1997; Rodbell et al., 2002; La Frenierre et al., 2011), as well as tephrochronological work (Heine, 1995).

This article aims at giving an overview of the current knowledge on glaciations in the northern tropical Andes $\left(11^{\circ} \mathrm{N}-4^{\circ} \mathrm{S}\right)$, using the glacial geochronological literature with values reported from the original publications (Table 1, see supplementary material at http://publicaciones.unirioja.es/revistas/cig2017/Angel_Table01.xls). It is noteworthy that the confidence in radiocarbon dating has improved considerably over the past years. It is also important to note that different scaling schemes and production rates to calculate surface exposure ages were used in the original publications for Terrestrial Cosmogenic Nuclide ${ }^{10} \mathrm{Be}\left(\mathrm{TCN}-{ }^{10} \mathrm{Be}\right)$ (e.g. Wesnousky et al., 2012; Carcaillet et al., 2013; Angel, 2016). Production rates for ${ }^{10} \mathrm{Be}$ in the tropical Andes have only recently become available (e.g. Kelly et al., 2013). This means that $\mathrm{TCN}-{ }^{10} \mathrm{Be}$ ages can differ based on the exposure age calculation systematics used. The scale of the age differences can lead to changes in paleoclimate interpretations, especially the response of glaciers to shorter climate events such as the Younger Dryas (e.g. Carcaillet et al., 2013; Angel et al., 2016).

A summary of the Quaternary Glaciation of the northern tropical Andes is presented in this article from North to South, covering Venezuela, Colombia and Ecuador, and from ancient to recent time. For more detail about each country, the reader may see further in the original literature.

\section{Early and Middle Pleistocene Glaciations}

\subsection{Venezuela}

Evidence of early Quaternary glaciations has not been reported. The lack of early glacial cover has been explained by (i) the assumption that the Mérida Andes reached a 
sufficient elevation to generate glaciers very late (Vivas, 1974; Giegengack and Grauch, 1975), or (ii) the assumption that the uplift rate was sufficiently high so each glaciation erased the evidence of the former one (Schubert, 1979; Schubert and Vivas, 1993). This last interpretation is based on the strong uplift and erosion rates between Late Miocene (ca. $10 \mathrm{Ma}$ ) to present (Kohn et al., 1984; Pindell et al., 1998). Quaternary uplift ranges between $\sim 0.7$ and 5 mm/a (Audemard and Audemard, 2002; Wesnousky et al., 2012; Guzmán et al., 2013).

The knowledge on glaciations is limited for the Early and Middle Pleistocene (Mahaney et al., 2010a; Kalm and Mahaney, 2011). Evidences of paleo-glacial cover are observed in the Chama, Mucujún (at $2600 \mathrm{~m}$ a.s.1.), Aracay and Santo Domingo river valleys (Tricart, 1966; Schubert, 1984) (Fig. 1, Site 1), with isolated outcrops of diamicton (Schubert, 1984). In addition, evidences of paleo-glacial cover have been observed in the Mesa del Caballo (Fig. 1, Site 2), based on LAG 4 and LAG 5 sections at $\sim 3500 \mathrm{~m}$ a.s.l. (Mahaney et al,. 2010a). The authors relate these LAG sections to the penultimate glacial, based on the superposition of PED 5 section. This PED 5 is a $40 \mathrm{~m}$ section from the Mesa del Caballo composed of till deposits, glaciolacustrine sediments and paleosols (Dirszowsky et al., 2005). The base of the PED 5 section was dated at $60 \mathrm{ka}$ based on radiocarbon dating (Dirszowsky et al., 2005).

Evidence of two glacier advances were found at LAG 4 and LAG 5 sections, based on differences in the weathered state of light and heavy minerals between till layers in LAG 5 (equivalent to the entire LAG 4 section) (Mahaney et al., 2010a). These authors identified an abrupt relation between these two glacier advances, which indicate a hiatus of unknown duration. The weathered state of sands with clay mineral composition in the paleosols of LAG 4 and LAG 5 suggests an older age in the Pleistocene. The authors proposed that the ice source was initially located 2-4 km to the south of Mesa del Caballo. This assumption is based on the Boconó fault movement. The ice source was located at the south of the Mucuchache valley in the Sierra Nevada (Fig. 1, Site 3).

\subsection{Colombia}

Evidences of the Late Pliocene-Quaternary boundary are recognized in the Eastern Cordillera, specifically at the Bogotá Plain and surrounding mountains (Fig. 1, Site 4). Before this period, the Eastern Cordillera was probably not high enough to support glaciers (Helmens, 2011). In the Bogotá region, major tectonic uplift of approximately $2000 \mathrm{~m}$ is recorded between 6 and 3 Ma (Van der Hammen et al., 1973; Kuhry and Helmens, 1990; Wijninga, 1996).

A distinct lithological transition is observed surrounding the Bogotá Plain in the Páramo de Palacio (between 3000-3500 m a.s.l.) (Fig. 1, Site 5) (Helmens, 2011). At higher elevations, moraine deposits are developed towards the glaciofluvial-lacustrine sediment in the basin (integrated by Río Chisaca, Río Siecha, Río Tunjuelito, Subachoque, Guasca Member and San Miguel formations) (Helmens, 2011). In this area, two major outcrops of glaciofluvial sediments (Guasca and Subachoque sections) expose a thickness of $75 \mathrm{~m}$. The Guasca Member underlies the Subachoque Formation. Interbeded tephras were 
sampled for fission track dating. The Guasca Member yielded fission-track ages of ca. 3 and 2.9 Ma, whereas the Subachoque Formation yielded fission-track ages of ca. 2.5, 1.7 and $1 \mathrm{Ma}$ (Helmens et al., 1997a).

More extensive glaciations are recorded in the upper part of the Subachoque Formation, based on changes of magnetic susceptibility (MS) recorded by lithology and magnetic geochronology (Helmens et al., 1997a). The upper part of the Subachoque was dated near the Matuyama/Brunhes magnetic Chron boundary at 0.8 Ma (Helmens et al., 1997a).

A shift towards higher magnitude climatic oscillations is also recorded at the Bogotá Plain (the upper part of the Funza pollen sequence at $3000 \mathrm{~m}$ a.s.1.), and has been placed at ca. $0.8 \mathrm{Ma}$ based on fission-track dating and land-sea correlation (Andriessen et al., 1993; Hooghiemstra et al., 1993; Hooghiemstra and Ran, 1994). This switch has been related to a distinct change in the frequency of planetary oscillations from 41 to $100 \mathrm{ka}$ climate cycles (Hooghiemstra et al., 1993).

\subsection{Ecuador}

The oldest evidences of glaciations in the Ecuadorian Andes have been recorded at the Rucu Pichinca in the Western Cordillera (Fig. 1, Site 6). In this area, six moraine complexes were identified (M1-M6, oldest to youngest) (Heine, 1995; Heine and Heine, 1996). The moraine complex M1 is the oldest one and is located between 3550$3600 \mathrm{~m}$ a.s.1. It is oxidized and deeply weathered, and overlies a deeply weathered lava flow dated at $>0.9$ Ma based on fission track method (Rosi, 1989, reported in Heine and Heine, 1996). Correlative moraine complex were identified in Potrerillos plateau, specifically in the Papallacta valley (Fig. 1, Site 7). In this last area, a lava flow fills the valley and is deformed by moraines M1 (at < $3400 \mathrm{~m}$ a.s.1.). This lava flow has been dated at $>150-180 \mathrm{ka}$ based on the fission-track method (Heine, 1995).

At $2750 \mathrm{~m}$ a.s.1. in the Chimborazo and Carihuairazo Massif (Fig. 1, Site 8), old till deposits with different weathering rates are probably from MIS 8 . This assumption is based on weathering and oxidation rates of a separate till constrained by a minimum radiocarbon age of $>43 \mathrm{ka}$ (Clapperton, 1990). In addition, to the south of Chimborazo and Carihuairazo Massif, in the Cajas National Park (Fig. 1, Site 9), previous MIS 5 glacier advances were proposed (Clapperton, 1986). These glacier advances were established based on weathered till exposed at $2800 \mathrm{~m}$ a.s.l. in the Río Tomebamba valley at the west of Cuenca (Fig. 1, Site 9).

\section{Late Pleistocene Glaciations}

\subsection{MIS 5 to MIS 3}

\subsubsection{Venezuela}

Late Pleistocene glaciations are evidenced in the Mérida Andes by two moraine complexes located between 2600-3400 m a.s.1. (Schubert, 1974). These moraines represent 
the main glacier advances in the Venezuelan Andes. The lowest glacier advances arrived at 2600-2800 m a.s.1., and are characterized by extremely weathered till, deeply eroded and covered by abundant vegetation (Schubert, 1974). These glacier advances were assigned to the locally named Early and Late Mérida Glaciation (Schubert, 1974). The Early Mérida Glaciation is poorly constrained and occurred during MIS 5-MIS 4. Few geochronological data are available from the area and ages range between $\sim 90$ and $\sim 60 \mathrm{ka}$ (Mahaney et al., 2000; Mahaney et al., 2001; Dirszowsky et al., 2005; Mahaney et al., 2010b). One data point is in the RF3 section of the La Canoa moraine in the Pueblo Llano valley at $2800 \mathrm{~m}$ a.s.1., Cordillera de Trujillo (Fig. 1, Site 10). A glaciotectonized diamict at the base of the RF3 section was dated at $81 \mathrm{ka}$ using optically-stimulated luminescence (OSL; Mahaney et al., 2000). A glacier advance was recently proposed in the Pueblo Llano valley at around $2500 \mathrm{~m}$ a.s.l. and dated at $72 \mathrm{ka}$ based on TCN- ${ }^{10} \mathrm{Be}$ (Angel, 2016). However, this lower Pueblo Llano moraine was proposed based on geomorphological description in aerial photographs and a light field work; a detailed sedimentological description is necessary to verify this proposal. In addition, a glacier advance older than $60 \mathrm{ka}$ BP was identified in the PED 5 section of the Mesa del Caballo at $3600 \mathrm{~m}$ a.s.1., based on radiocarbon dating of a peat bog layer (Dirszowsky et al., 2005).

MIS 3 glacier advances have been recently proposed at different locations of the Mérida Andes, based on TCN $-{ }^{10} \mathrm{Be}$ dated moraine boulders (Angel, 2016). A glacier advance was dated at $\sim 50 \mathrm{ka}$ in the Pueblo Llano Valley at around $2500 \mathrm{~m}$ a.s.l. However, this Pueblo Llano Valley moraine was proposed based on geomorphological description in aerial photographs and a light fieldwork; a detailed sedimentological description is necessary to verify this proposal. Angel (2016) also proposed glacier advances between 30-36 ka in the Sierra Nevada (Fig. 1, Site 3), specifically in the Mucuchache Valley (at $3400 \mathrm{~m}$ a.s.1.) and El Caballo moraine (at $3600 \mathrm{~m}$ a.s.1.). Glacial geomorphic landforms in the Mucuchache Valley were also studied by González (1995) and González and Bezada (2001) without providing chronological constraints.

\subsubsection{Colombia}

Glaciation during MIS 5-MIS 4 is likely related to the moraine complex 1, located at different elevations in the Eastern Cordillera (Fig. 1, Site 4) (Helmens, 1988). The author identified four moraine complexes (1-4) around the high plain of the Bogotá basin. Moraine complex 1 is the lowest in the landscape, and it is located below Páramo de Palacio at around $3000 \mathrm{~m}$ a.s.l. This moraine complex shows clear evidence of intense erosion, and denudation occurs in the apical zone of the large fluvio-glacial fans.

In Páramo de Sumapaz, the moraine complex 1 is located along Río Chisaco at 3350 m a.s.l. and along Quebrada Piedra Gorda at 3150 m a.s.l. (Helmens, 1990). Along Río Chisaco, a paleosol directly overlying the moraine complex 1 was radiocarbon dated at $30.93 \pm 0.42 \mathrm{ka} \mathrm{BP}$ (Helmens, 1990). At Cuchilla Boca Grande, a paleosol was also radiocarbon dated at $31.35 \pm 0.5 \mathrm{ka} \mathrm{BP}$ (Helmens, 1990). This paleosol was overlying material which seems to be reworked sediments of moraine complex 1 (Helmens, 1990; Helmens and Kuhry, 1995) (Fig. 1, Site 11). In addition, organic rich clay overlying a basal till was radiocarbon dated at $38 \mathrm{ka} \mathrm{BP}$. Therefore, the oldest till studied in Páramo Sumapaz is earlier than $38 \mathrm{ka}$. 
The Páramo Peña Negra is located at around $70 \mathrm{~km}$ to the North of Cuchilla Boca Grande (Fig. 1, Site 12). A reworked supraglacial till from moraine complex 1 is found at $2850 \mathrm{~m}$ a.s.1. (Helmens, 1988). A palaeosol developed on the till has been radiocarbon dated at $35.8 \pm 1.1 /-0.9 \mathrm{ka} \mathrm{BP}$.

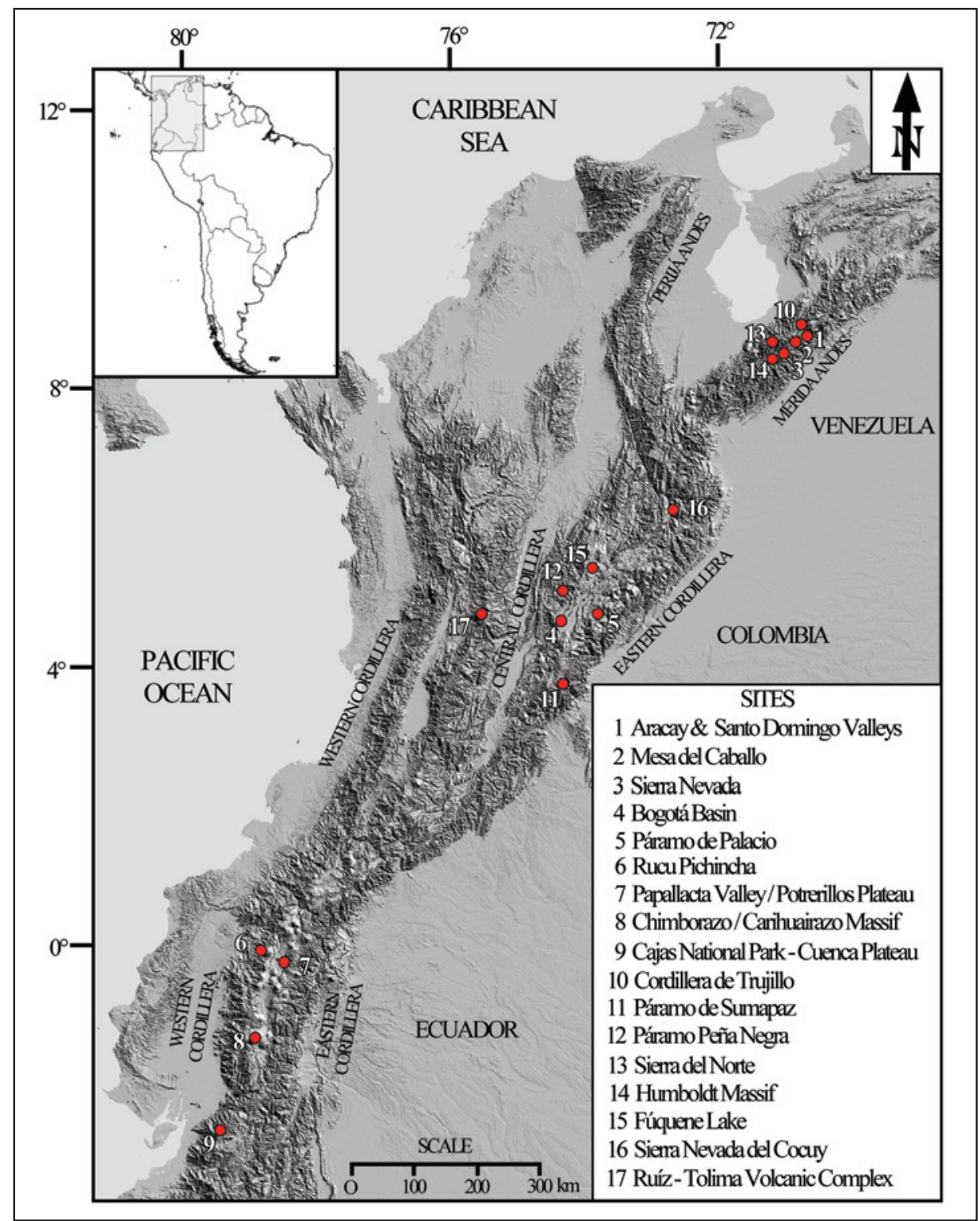

Figure 1. Location of different studied areas to reconstruct glaciations in the northern tropical Andes on shaded relief map based on SRTM (Shuttle Radar Topographic Mission). Numbers of the studied areas are in accordance with the text order appearance. 


\subsubsection{Ecuador}

Glaciations related to MIS 5-MIS 3 have mainly been studied using till deposits in the Chimborazo/Carihuairazo Massif (Clapperton and McEwan, 1985; Clapperton, 1986; Clapperton, 1987; Clapperton, 1990). A till deposit was radiocarbon dated older than 43 ka BP (Clapperton, 1990). The author proposed the till deposit as a glacier advance which occurred during MIS 4 ( 70 ka) or even MIS 6 (before $132 \mathrm{ka}$ ).

Clapperton and McEwan (1985) identified three groups of moraines in the Río Mocha Valley at the southwest side of the Carihuairazo volcano (Fig. 1, Site 8). General ages as full glacial (Group 3 below 3600 m a.s.1.), Lateglacial (Group 2, located between 3900 and $4050 \mathrm{~m}$ a.s.1.), and Neoglacial (Group 1, located between 4300 and $4400 \mathrm{~m}$ a.s.1.) based on radiocarbon dating were assigned. Clapperton and McEwan (1985) dated peat from Group 3 moraines. The upper layer of peat was dated at $35.44 \pm 0.68 / 0.63 \mathrm{ka} \mathrm{BP}$; the lower peat layer was beyond the limit of radiocarbon dating (>40 ka BP). Clapperton and McEwan (1985) also radiocarbon dated peat layers within laminated fine sediments underlying till located up valley Group 2 moraines; ages were $10.65 \pm 0.06 \mathrm{ka} \mathrm{BP}$ and $11.37 \pm 0.06 \mathrm{ka} \mathrm{BP}$.

Clapperton (1987) dated peat deposits at altitudes between 3725-3870 m a.s.l. on the north and northeast flanks of the Carihuairazo volcano. Radiocarbon dates from peat lying between the uppermost and the other two till layers (of three) fell between $33 \mathrm{ka} \mathrm{BP}$ (uppermost peat) and $>40 \mathrm{ka} \mathrm{BP}$ (basal peat).

Weathered till deposits probably older than Group 3 have been observed between 2750-2800 m a.s.1. These weathered till deposits are located in the Río Mocha Valley and Río Tomebamba Valley west of Cuenca (Clapperton and McEwan, 1985; Clapperton, 1986). Soil overlying $20 \mathrm{~m}$ of the Cuenca Plateau till was beyond the limit of radiocarbon dating (>40 ka BP) (Clapperton, 1986). Clapperton (1986) concluded that around $2800 \mathrm{~m}$ a.s.l. marked the absolute limits of Quaternary glaciations in the Ecuadorian Andes.

\subsection{MIS 2 to Younger Dryas (YD)}

\subsubsection{Venezuela}

Studied glacial evidences during MIS 2 and MIS 1 mainly consist of moraines and roches moutonnées. These glacial landforms have been studied in the Sierra Nevada (including Sierra de Santo Domingo) (e.g. Mahaney et al., 2008; Stansell et al., 2007; Wesnousky et al., 2012; Carcaillet et al., 2013; Angel, 2016), Sierra del Norte (e.g. Wesnousky et al., 2012; Angel, 2016) and Cordillera de Trujillo (e.g Bezada, 1989; Mahaney et al., 2001; Guzmán, 2013; Angel, 2016) (Fig. 1, Sites 3, 13 and 10 respectively). In addition, evidences of glacial cover are also based on palynological studies of glacial lakes sediments (e.g. Rull, 2010; Stansell, 2010).

The global Last Glacial Maximum (gLGM) between 23-14 ka BP with a midpoint at $18 \mathrm{ka}$ BP was originally proposed (CLIMAP Project Members, 1976, 1981; Shackleton et al., 1977). However, Shakun and Carlson (2010) suggested that a global 
average age of $22.2 \pm 4.0$ ka best defines the gLGM, based on 56 terrestrial records. The LGM in the Mérida Andes was established based on palynological analysis of PED5 section between 22.75 and $19.96 \mathrm{ka} \mathrm{BP}$ (Fig. 1, Site 2) (Schubert and Rinaldi, 1987). Temperatures were at least $8.8 \pm 2{ }^{\circ} \mathrm{C}$ cooler than currently, based on Equilibrium Line Altitudes (ELA) variations (Stansell et al., 2007).

LGM glacier advances are related to Las Tapias terminal moraines and frontal moraines in the Mucubají Valley, both in the Sierra Nevada (Angel, 2016) (Fig. 1, Site 3). Las Tapias terminal moraine has been dated at $19 \mathrm{ka}$ based on $\mathrm{TCN}-{ }^{10} \mathrm{Be}$ (Angel, 2016). This terminal moraine is located at $3100 \mathrm{~m}$ a.s.l.

In the Mucubají Valley, a frontal moraine at around $3600 \mathrm{~m}$ a.s.1. was $\mathrm{TCN}-{ }^{10} \mathrm{Be}$ dated at 22-20 ka (modified ages of Carcaillet et al., 2013, in Angel, 2016). However, a maximum glacier advance is observed from a damaged terminal undated moraine at elevations lower than $3589 \mathrm{~m}$ a.s.l. It is likely that the damaged moraine is not much older than $22 \mathrm{ka}$, and probably corresponds to the local LGM (Angel, 2016). In addition, $\mathrm{TCN}-{ }^{10} \mathrm{Be}$ ages of the Mucubají frontal moraines at around $3600 \mathrm{~m}$ a.s.l. are in agreement with a previous radiocarbon age. This radiocarbon age was 19.08 $\pm 0.82 \mathrm{ka}$ BP from an outwash fan located at $3400 \mathrm{~m}$ a.s.1. (Schubert and Rinaldi, 1987).

The Oldest Dryas (OtD) was a cold period originally proposed based on biostratigraphic changes in terrestrial records of Denmark (Iversen, 1954). Blunier et al. (1998) proposed the OtD period between 17.50 to14.60 Cal ka BP. In the Mérida Andes, a cold period named El Caballo Stadial was established at $16.5 \mathrm{ka} \mathrm{BP}$, based on palynological analysis of the Mesa del Caballo (Rull, 1998).

In the Sierra Nevada, specifically in the Mucubají and Gavidia valleys, glacial expansion during the LGM-OtD has been recognized. In the Mucubají Valley, glacier advances related to the LGM-OtD are located around $3500 \mathrm{~m}$ a.s.l. (Angel, 2016). In the Gavidia valley (at 3100 to $4200 \mathrm{~m}$ a.s.1.), former glacier maximum extent happened at around $21 \mathrm{ka}$, and complete valley deglaciation occurred at around $16 \mathrm{ka}$ (Angel et al., 2016). This chronological data was mainly based on $\mathrm{TCN}-{ }^{10} \mathrm{Be}$ exposure dating of roches moutonnées.

In the Sierra Nevada, particularly in Sierra Santo Domingo, LGM-OtD maximum glacier advances are related to the La Victoria terminal moraine. This terminal moraine is located at around $3140 \mathrm{~m}$ a.s.l. and dated to a weighted average age of $17.45 \pm 0.47 \mathrm{ka}$ (Angel, 2016). Another LGM-OtD glacier advance has been constrained at the Los Zerpa terminal moraine located at $\sim 3100 \mathrm{~m}$ a.s.1., and a weighted average exposure age of $18.30 \pm 0.46 \mathrm{ka}$ (modified ages of Wesnousky et al., 2012 and Carcaillet et al., 2013 in Angel, 2016). All these moraines (La Victoria, Los Zerpa) chronological data, is based on $\mathrm{TCN}-{ }^{10} \mathrm{Be}$ of frontal moraine boulders.

In Sierra del Norte, La Culata moraines are located between $3160 \mathrm{~m}$ and $3500 \mathrm{~m}$ a.s.1. Weighted average TCN $-{ }^{10} \mathrm{Be}$ ages of $16.88 \pm 0.22 \mathrm{ka}$ and $17.78 \pm 0.78 \mathrm{ka}$ and $17.94 \pm 0.47 \mathrm{ka}$ of these moraines, are related to LGM-OtD glacier advances (Wesnousky et al., 2012; Angel, 2016). Whereas El Desecho moraine (at $3500 \mathrm{~m}$ a.s.1.), was dated at $17.97 \pm 0.58 \mathrm{ka}$, based on $\mathrm{TCN}-{ }^{10} \mathrm{Be}$ of terminal moraine boulders (Angel, 2016). 
In the Cordillera de Trujillo, the La Canoa terminal moraine is related to a LGMOtD glacier advance ( $2800 \mathrm{~m}$ a.s.1., weighted average TCN $-{ }^{10} \mathrm{Be}$ age of $\left.17.89 \pm 1.09 \mathrm{ka}\right)$ (Angel, 2016). The $\mathrm{TCN}-{ }^{10} \mathrm{Be}$ ages agree with glaciofluvial sediments dated inside the La Canoa moraine at $18.0 \pm 2.1 \mathrm{ka}$ by Thermoluminescence (TL) (Bezada, 1989). Finally, a moraine located between La Capellanía and El Pozo in the Pueblo Llano Valley with a weighted average TCN- ${ }^{10} \mathrm{Be}$ age of $17.32 \pm 1.72 \mathrm{ka}(\sim 2300 \mathrm{~m}$ a.s.1.) (Guzmán, 2013) could also be related. It seems to indicate that in the Mérida Andes, glaciers had their maximum extent during the Late Mérida Glaciation at elevations lower than those originally proposed by Schubert (1974) (< 3000 m a.s.1.) (Guzmán, 2013). Late Mérida Glaciation is established between 25-13 ka BP (Schubert, 1974).

Features of glaciations during MIS 1 have mainly been recorded based on sedimentological and chronological studies of glacial lake sediments (e.g. Stansell and Rull, 2010). A Younger Dryas (YD) glacier advance was recorded close to Lago Verde ( $4000 \mathrm{~m}$ a.s.l.) in the Humboldt Massif (Sierra Nevada), at a radiocarbon date of $10.52 \pm 2.00 \mathrm{ka} \mathrm{BP}(12.40 \mathrm{Cal}$ ka BP) (Fig. 1, Site 14) (Mahaney et al., 2008). Moreover, in the Humboldt Massif a YD glacier advance was also suggested from geochemical and sedimentological analyses of Laguna Los Anteojos at $4045 \mathrm{~m}$ a.s.1. (Stansell et al., 2010).

In the Mucubají Valley, a small push moraine located at $23700-3800 \mathrm{~m}$ a.s.l. has been linked to the YD (site MUM7B, Mahaney et al., 2008). This assumption is based on peat samples covered by glaciofluvial materials which have been radiocarbon dated at $13.29 \pm 0.22,13.64 \pm 0.15$ and $13.66 \pm 0.44 \mathrm{ka} \mathrm{BP}$. These glaciofluvial materials are located down-dip from the push moraine (Mahaney et al., 2008). However, this push moraine is older than $14 \mathrm{ka}$; it is not in agreement with a YD glacier advance (Angel, 2016). New TCN $-{ }^{10} \mathrm{Be}$ ages support this assumption. The push moraine is surrounded by glacial landforms dated at 15.4 $\pm 1.4 \mathrm{ka}$ (MU15-09 sample) and 16.8 $\pm 0.8 \mathrm{ka}$ (MU08-09 sample) (modified ages of Carcaillet et al., 2013 in Angel, 2016). A YD glacier advance could rather be related to a moraine located at $3862 \mathrm{~m}$ a.s.l at $12.0 \pm 1.0 \mathrm{ka}$ based on TCN- ${ }^{10} \mathrm{Be}$ exposure ages (Angel, 2016).

Abrupt colder and drier climate conditions in Sierra Nevada-Mérida Andes occurred between $12.85 \mathrm{ka}$ and $11.75 \mathrm{ka}$ (Stansell et al., 2010). This assumption is derived from geochemical and clastic sediment analyses from Laguna Los Anteojos at $3900 \mathrm{~m}$ a.s.1. These authors established that the maximum glacier extension happened at $12.65 \mathrm{ka}$. ELA values were $\sim 360$ to $480 \mathrm{~m}$ lower than today, and temperature between $2.2-2.9{ }^{\circ} \mathrm{C}$ colder than today. Rull et al. (2010) using a palynological analysis from Laguna Los Anteojos, also determined cold climate conditions between $12.86 \mathrm{ka}$ and $11.65 \mathrm{ka}$ with temperatures ranging between $2.5-3.8{ }^{\circ} \mathrm{C}$ colder than present. Carrillo et al. (2008) determined cold climate conditions during the YD in Sierra Nevada at $\sim 12.8 \mathrm{ka} \mathrm{BP}$, based on magnetic susceptibility in a sediment core from the Mucubají Lake. Abrupt warming at the onset of the Holocene ( 11.6 ka BP) was also recognized by Carrillo et al. (2008).

\subsubsection{Colombia}

In the Eastern Cordillera at the Bogotá Plain two moraine complexes (2 and 3) have been linked to the LGM and LGM-OtD period. Moraine complex 2 is located at 
Páramo de Peña Negra (Fig. 1, Site 12) between 3000-3550 m a.s.l. (Helmens, 1988). Minimum ages for the moraine complex were obtained from organic-rich sediments. Such sediments were overlying glaciofluvial gravel directly behind moraine complex 2 (Helmens, 1988). Radiocarbon ages were 19.19 $\pm 0.12 \mathrm{ka} \mathrm{BP}$ and $18.13 \pm 0.17 \mathrm{ka} \mathrm{BP}$. Moraine complex 2 is probably younger than $23 \mathrm{ka} \mathrm{BP}$ (Helmens 1988).

Moraine complex 3 at the Bogotá Plain is located between 3100-3750 m a.s.1. (Helmens 1988). Ages for basal lake sediments enclosed by moraine complex 3 were $14.46 \pm 1.70 \mathrm{ka} \mathrm{BP}$ and $15.51 \pm 0.19 \mathrm{ka} \mathrm{BP}$ at $3650 \mathrm{~m}$ a.s.l., based on radiocarbon dating (Helmens et al., 1997b). Moraine complex 3 was dated between $18.13 \pm 0.17 \mathrm{ka}$ $\mathrm{BP}$ and $14.66 \pm 0.28 \mathrm{ka}$ BP (Helmens, 1988). These glacier advances during the LGMOtD period were related to the Fúquene Stadial (Helmens, 1988), which was established between 21 to $14 \mathrm{ka} \mathrm{BP}$, according to palynological analysis from the Fúquene Lake sediments 100 km NE from Bogotá (van Geel and van der Hammen, 1973).

YD glacier advances at the Bogotá Plain could be represented by moraine complex 4, located at Páramo de Sumapaz between $~ 3250-3400 \mathrm{~m}$ a.s.l. (Fig. 1, Site 11). Bracketed radiocarbon ages of moraine complex 4 are $12.99 \pm 0.19 \mathrm{ka} \mathrm{BP}$ and $12.76 \pm 0.16 \mathrm{ka} \mathrm{BP}$ (Helmens, 1988). Dated samples were light-brown lacustrine clays, which were located directly overlying the rocky subsoil in the area immediately behind the moraines (Helmens, 1988).

In the Eastern Cordillera at the western slopes of the Sierra Nevada del Cocuy, three drifts or till deposits were recognized in altitudes above $2900 \mathrm{~m}$ a.s.l. These drifts were numbered 3-6 (old to young) (van der Hammen et al., 1980/1981). Laguna Ciega is located up valley drift 3. The sedimentation in such lake probably began between 24.5-27.0 ka BP, based on radiocarbon dating (van der Hammen et al., 1980/1981 in Helmens et al., 1997). In addition, other drifts have been identified in the Sierra Nevada del Cocuy (Fig. 1, Site 16). These drifts were named 1 and 2 (Helmens et al., 1997). Drift 2 includes isolated moraines located at the eastern slopes, and glacial origin of drift 1 is unknown (Helmens et al., 1997).

In the Sierra Nevada del Cocuy, different moraine complexes have been identified, named Lower Bocatoma, Corralito, Lagunillas, Cóncavo and Río Negro. Lower Bocatoma and Corralito moraines are located below drift 5 (altitudes between 3800-4000 $\mathrm{m}$ a.s.1.) (Helmens, 2011). Lagunillas moraines were divided in Upper ( 3600 m a.s.1.) and Lower ( 3400 m a.s.1.) moraines (Helmens, 2011) as were the Cóncavo moraines, respectively ( $\sim 3300 \mathrm{~m}$ and $\sim 2900 \mathrm{~m}$ a.s.1.), whereas Río Negro moraines are located between 2600$2800 \mathrm{~m}$ a.s.l. (Helmens, 2011).

A peat layer in the lake sediments located between Upper Lagunillas moraines and Lower Bocatoma moraines was radiocarbon dated at $12.32 \pm 0.10 \mathrm{ka}$ BP (Helmens, 2004, in Helmens, 2011). In the inner part of the Lower Bocatoma moraines, a peat deposit was radiocarbon dated at $8.54 \pm 0.26 \mathrm{ka} \mathrm{BP}$ (Helmens, 2004, in Helmens, 2011). This radiocarbon date was interpreted as the vegetation colonization of moraines, so deglaciation occurred sometime between 12-8 ka.

Deglaciation of the Upper Lagunillas moraines occurred between 12-10 ka (González et al., 1966 in Helmens, 2011). Lake sediments radiocarbon dated up valley Upper Lagunillas moraines indicated that sedimentation began between $11.35 \pm 0.14$ ka BP and $10.03 \pm 0.09$ ka BP (González et al., 1966 in Helmens, 2011). 
In the Eastern Cordillera, the palynological records indicate a cooling event named El Abra Stadial, which was radiocarbon dated between 10-9.5 ka BP (van Geel and Van der Hammen, 1973; Kuhry et al., 1993). Coldest and driest climate conditions between radiocarbon dates of 11.0-10.5 Cal ka BP have also been interpreted (van't Veer et al., 2000).

In the Central Cordillera Thouret et al. (1996) provided chronology of moraines in the Ruiz-Tolima volcanic complex (Fig. 1, Site 17). Moraine chronologies were based on radiocarbon dating and inter-site correlation using tephra, paleosols and peat stratigraphy. One of the studied moraines was Río Recío at around $3200 \mathrm{~m}$ a.s.l. These moraines were radiocarbon dated at between $28 \mathrm{ka} \mathrm{BP}$ and $42 \mathrm{ka} \mathrm{BP}$, suggesting that glaciers were more extensive before the gLGM.

Another moraine complex in the Central Cordillera is named Murillo moraines, which represent two phases of glacier advances. Murillo moraines are located between 3300-3400 m a.s.l. and were radiocarbon dated between 28-16 ka BP (Thouret et al., 1996). These two glacier advances were related by the authors to Early (21-19.5 ka BP) and Late (17-14 ka BP) Fúquene Stadial. The Early Murillo moraines are the biggest moraines in the Ruiz-Tolima area (Helmens, 2011).

\subsubsection{Ecuador}

In the Chimborazo/Carihuairazo Massif, two moraine complexes (G2 at 3900$4050 \mathrm{~m}$ a.s.l. and G1 at 4300-4400 m a.s.1.) are related to MIS 2-MIS 1 glacier advances, based on radiocarbon ages of $10.7 \pm 0.1$ and $11.4 \pm 0.1 \mathrm{ka} \mathrm{BP}(\mathrm{G} 2$ moraines between 12.7 and 13.4 Cal. ka BP) (Clapperton and McEwan, 1985). Samples were collected on the upper and lower peat layers within laminated fine-grained sediments underlying the till. Peat layers were located in a drained glacial lake up valley of the G2 moraines. Based on morphostratigraphical analysis, G1 moraines are younger than G2 moraines. G1 ages were not presented.

In the Rucu Pichincha (Fig. 1, Site 6), MIS 2 and MIS 1 glacier advances have been attributed to moraines M4 (at $3700 \mathrm{~m}$ a.s.1.), M5 (between 4100-4200 m a.s.1.) and M6 (between 4200-4400 m a.s.1.) (Heine and Heine, 1996). Peat from a paleolake/bog enclosed by M5 moraines gave a minimum-limiting radiocarbon ages of 11.2 $\pm 0.1 \mathrm{ka} \mathrm{BP}(13.0 \mathrm{Cal}$. $\mathrm{ka} \mathrm{BP})$ and $13.0 \pm 0.1 \mathrm{ka} \mathrm{BP}(15.5 \mathrm{Cal} . \mathrm{ka} \mathrm{BP})$. Heine (1995) proposed that the M4 moraines were deposited during the gLGM. Bracketed ages for M6 moraines were between $11.2 \pm$ 0.1 ka BP (underlying peat was 13.0 Cal. ka BP) and 8.2-9.0 ka (overlying HL-4 tephra from Rosi, 1989, in Heine and Heine 1996). M6 could be related to a YD glacier advance.

In the Cajas National Park, Hansen et al. (2003) recognized MIS 2 and MIS 1 glacier advances located between 3700-3080 m a.s.1. (moraine complex GZ). Glacial chronological data were based on radiocarbon ages from lacustrine sediments. Three moraines are part of this group, Z1 (at $3760 \mathrm{~m}$ a.s.1.), Z2 (at $3360 \mathrm{~m}$ a.s.1.) and Z3 (3080 m a.s.1.). Between $\mathrm{Z1}$ and Z2, Laguna Chorreras is located at $3700 \mathrm{~m}$ a.s.1., whereas Laguna Pallcacocha is located up valley $\mathrm{Z1}$ at $\sim 4060 \mathrm{~m}$ a.s.1. Hansen et al. (2003) reported a radiocarbon age of $13.2 \pm 0.1 \mathrm{ka}$ BP from the organic material collected in the Laguna Chorreras. Sedimentation onset was estimated at 17.0 Cal. ka BP. The oldest radiocarbon age in the 
Pallcacocha lacustrine sediments core was $11.8 \pm 0.1 \mathrm{ka} \mathrm{BP}$, and the sedimentation onset was estimated at 14.5 Cal. ka BP (Hansen et al., 2003). Therefore, Z1 ages are between 14.5-17.0 Cal. ka BP and Z2 and Z3 older than 17.0 Cal. ka BP.

In the Papallacta valley, MIS 2 and MIS 1 glacier advances are evidenced in the M4 or Sucus moraines (at $3850 \mathrm{~m}$ a.s.1.), M5 or Potrerillos moraines (at 3900 m a.s.1.) and M6 moraine (at $4055 \mathrm{~m}$ a.s.1.) (Heine, 1995; Heine and Heine, 1996; Clapperton et al., 1997). Heine (1995) and Heine and Heine (1996) related the M4 moraines to the gLGM. Authors proposed that M5 moraines were created between the radiocarbon date of $12.3 \pm 1.3 \mathrm{ka} \mathrm{BP}$ and the gLGM. Meanwhile, the M6 moraine has been related to the Lateglacial (bracketed by radiocarbon ages of $10.5 \pm 0.8 \mathrm{ka} \mathrm{BP}$ below and $7.9 \pm 0.9 \mathrm{ka}$ BP above). Clapperton et al. (1997) disagreed with the interpretation of Heine (1995) about M4 moraines timing, which were divided into the Sucus (at $3850 \mathrm{~m}$ a.s.1.) and Potrerillos moraines (at 3950 m a.s.l.). Clapperton et al. (1997) reported that the Sucus advance occurred before $13.1 \mathrm{ka}$ BP (average age $\mathrm{n}=7$ and $15.6 \mathrm{Cal}$. ka BP). This radiocarbon date was based on plant material and peaty organic matter overlying till located between two Sucus lateral moraines. The Sucus advance occurred between 30 $\mathrm{ka}$ and $13 \mathrm{ka}$. This assumption was supported by a radiocarbon date of organic material located at $3500 \mathrm{~m}$ a.s.l. (Clapperton et al., 1997). This organic material was beneath two till layers separate by a lava flow (Clapperton et al., 1997).

The Potrerillos moraines were bracketed between radiocarbon ages of $10.9 \mathrm{ka}$ BP (average age $(\mathrm{n}=11) 12.8 \mathrm{Cal}$. $\mathrm{ka} \mathrm{BP})$ and $10.0 \mathrm{ka} \mathrm{BP}$ (average age $(\mathrm{n}=5) 11.3 \mathrm{Cal}$. ka BP). Clapperton et al. (1997) interpreted the Potrerillos advance as contemporaneous with the YD climate reversal.

\section{Discussions and conclusions}

\subsection{Oldest glaciation evidences}

The oldest dated glaciation evidences are observed at different elevations in the northern tropical Andes. The oldest glaciation evidences are recorded in the Colombian Andes at the Páramo de Palacio, Bogotá Plain-Eastern Cordillera (between 3000$3500 \mathrm{~m}$ a.s.1.) (Fig. 1, Site 5). Here major outcrops of glaciofluvial-lacustrine sediments (Guasca and Subachoque sections) have been dated by fission track between 1 and 3 Ma. In the Ecuadorian Andes, the oldest dated evidences (moraine complexes M1-M7) are located at Rucu Pichinca and Papallacta valleys, between 3400-3600 m a.s.l.; their ages range between $\sim 900 \mathrm{ka}-150 \mathrm{ka}$ (Fig. 1, Sites 6 and 7).

In the Venezuelan Andes, maximum dated glacial extent occurred during MIS 5 ( 90-80 ka). These glacial geomorphic deposits are located at $2800 \mathrm{~m}$ a.s.l. in the Pueblo Llano Valley, Cordillera de Trujillo (Fig. 1, Site 10). Though possible glaciation evidences related to the Early and Middle Pleistocene have been proposed in the Mérida Andes. These glaciation evidences have been proposed at the Chama, Mucujún (2600 m a.s.1.), Aracay, Santo Domingo river valleys and in the Mesa del Caballo (at $3500 \mathrm{~m}$ a.s.1.) (Fig. 1, Sites 1 and 2), geochronological constraints are not available. 


\subsection{Timing of glaciation maximum extent}

Maximum extent of former glaciers in the northern tropical Andes seems to have occurred before the gLGM. In the Venezuelan-Mérida Andes the former glaciers reached the lowest recorded elevations (2600-2800 $\mathrm{m}$ a.s.1) during MIS 5-MIS 4. Meanwhile, during the gLGM, they reached elevations between $\sim 3500 \mathrm{~m}$ a.s.l. and $3100 \mathrm{~m}$ a.s.l. Also in the Colombian Andes, the maximum extent of former glaciers was probably reached at ages older than the gLGM, before $38 \mathrm{ka}$, with elevations around $2800 \mathrm{~m}$ a.s.1. Also, for the Ecuadorian Andes, former glacier maxima likely occurred prior to the gLGM, probably during MIS 8, reaching elevations between $2700 \mathrm{~m}$ a.s.1. and $2800 \mathrm{~m}$ a.s.l. However, there is no accurate geochronological data to confirm this interpretation.

\subsection{Relationship between former glacier dynamics and cold paleoclimate events}

\subsubsection{During the LGM-OtD}

The LGM glacier advances in the northern tropical Andes are not commonly observed, and are located between $~ 3000-3500 \mathrm{~m}$ a.s.1. In the Venezuelan-Mérida Andes, these glacier advances are present in Sierra Nevada at around 3100-3500 m a.s.1., and dated at between 22-19 ka (Mucubají, Las Tapias moraines). In the Colombian Andes, LGM glacier advances seem to be present in the Eastern Cordillera (Bogotá Plain-morainic complex 2) (Fig. 1, Site 12) and in the Central Cordillera (lower Murillo moraines). These glacier advances are located between 3000 and $3500 \mathrm{~m}$ a.s.l. In the Ecuadorian Andes, LGM glacier advances seem to be related to a moraine complex located in the Cajas National Park between 3000-3300 m a.s.1. (Fig. 1, Site 9).

In the tropical Andes, most of the studied glacier advances are related to a period that stretches from the final LGM to the OtD ( 18-15 ka). These glacier advances are observed between 2500-3800 m a.s.1. In the Venezuelan-Mérida Andes, they are located between 2500-3600 $\mathrm{m}$ a.s.1. Most of these advances could be related to the local cold event El Caballo stadial (at $16.5 \mathrm{ka} \mathrm{BP}$ ). Whilst most of the glaciers grew in this area, in the Gavidia valley (Sierra Nevada) former glacier extinction occurred at around $16 \mathrm{ka}$ at $\sim 4200$ m a.s.l.

In the Colombian Andes, glacier advances related to the final LGM-OtD period are located at the Bogotá Plain between 3100-3750 m a.s.l. (moraine complex 3), and dated between 18-15 ka: They are related to the Late Fúquene Stadial (17-14 ka). In the Central Cordillera, the Murillo moraines, located between 3300-3400 m a.s.1., may also be associated to the Late Fúquene Stadial.

Glacier advances related to the final LGM-OtD period in the Ecuadorian Andes, seem to be related to moraine complexes located in the Cajas National Park between 3360-3760 m a.s.1. $\left(\mathrm{Z}_{1}\right)$, as is the case for the Sucus moraine in the Papallacta Valley at $3850 \mathrm{~m}$ a.s.1. (Fig. 1, Site 7). 


\subsubsection{During the $Y D$}

Abrupt colder and drier climate conditions in the Sierra Nevada Cordillera of the Venezuelan-Mérida Andes occurred between $12.85 \mathrm{ka}$ and $11.75 \mathrm{ka}$. Temperatures were 2.5-3.8 ${ }^{\circ} \mathrm{C}$ colder than present. However, evidence of glacier advances during this period is limited so far. Only two YD glaciers advances have been recorded in the Sierra Nevada at elevations higher than $3860 \mathrm{~m}$ a.s.l. (3862 m a.s.l. in the Mucubají valley and $4000 \mathrm{~m}$ a.s.l. in the Humboldt Massif). Concerning the Colombian Andes, limited evidences of glacier advances during the YD are available. One of these evidences is constrained to the Eastern Cordillera, Sierra Nevada del Cocuy (Fig. 1, Site 16), e.g. the Lower Bocatoma moraines (at between 3800 and $4000 \mathrm{~m}$ a.s.l.) and the Upper Lagunillas moraines, at around $3600 \mathrm{~m}$ a.s.1. In addition, the moraine complex 4 (between 3250-3700 m a.s.l.) at Páramo de Sumapaz, Bogotá Plain (Fig. 1, Site 11), are examples of the YD glacier advances. Finally, in the Ecuadorian Andes, glacier advances during the YD are not extensively observed. They could be connected to the G2 moraines in the Chimborazo/Carihuairazo Massif at elevations between 3900-4050 m a.s.l. (Fig. 1 , Site 8 ). In addition, glacier advances during this period could also be associated to the M6 moraines in the Rucu Pichincha, between 4200 and 4400 m a.s.l. (Fig. 1, Site 7). Evidence of glacier advances during the YD can be identified in the Papallacta valley, namely the Potrerillos moraines, at around $3900 \mathrm{~m}$ a.s.l.

Limited evidences of YD glacier advances are available in the northern tropical Andes. These glacier advances, in general, are mainly located at the highest elevations (> 3500 m a.s.1.).

\subsection{Recent improvements on glacial knowledge and recommendation for future studies}

In the last decade, significant improvement in our knowledge of glaciation in the northern tropical Andes has been obtained in the Venezuelan-Mérida Andes, due to TCN${ }^{10}$ Be dating.

For a better reconstruction of glaciations in the northern tropical Andes, it is necessary to improve the knowledge of glacier dynamics during the YD and prior to MIS 5. To understand the glaciers cover during the $\mathrm{YD}$, new research should be performed at elevations higher than $\sim 3600-3800$ m a.s.l. Nevertheless, to understand glaciers dynamics prior to MIS 5, glacial geomorphological and geochronological work at elevations lower than $\sim 2600-2800 \mathrm{~m}$ a.s.l. needs to be conducted.

\section{Acknowledgements}

We would like to send our sincere thanks to researchers who provided us information, data and comments used to write this article, including: Karin Helmens, Bryan G. Mark, Ruben Basantes, Sergio Restrepo, Alessa Geiger and Jan Hegner. In addition, we are very grateful for the help of Alessa Geiger, Jan Hegner, Milagrosa Aldana, and Lisandro Estopiñan in order to improve the English of this manuscript, and two anonymous reviewers for their valuable recommendations. 


\section{References}

Andriessen, P.A.M., Helmens, K.F., Hooghiemstra, H., Riezebos, P.A., Van der Hammen, T. 1993. Absolute chronology of the Pliocene-Quaternary sediment sequence of the Bogotá area, Colombia. Quaternary Science Reviews 12, 483-501. http://doi.org/10.1016/0277-3791 (93)90066-U.

Angel, I. 2016. Late Pleistocene deglaciation histories in the central Mérida Andes (Venezuela). $\mathrm{PhD}$. Sc Thesis. Université de Grenoble Alpes-Universidad Central de Venezuela, Francia, Venezuela, 234 pp.

Angel, I., Carrillo, E., Carcaillet, J., Audemard, F.A., Beck C. 2013. Geocronología con el isótopo cosmogénico ${ }^{10} \mathrm{Be}$, aplicación para el estudio de la dinámica glaciar cuaternaria en la región central de los Andes de Mérida. GEOS 44, 73-82.

Angel, I., Audemard, F.A., Carcaillet, J., Carrillo, E., Beck, C., Audin, L. 2016. Deglaciation chronology in the Mérida Andes from cosmogenic ${ }^{10} \mathrm{Be}$ dating (Gavidia valley, Venezuela). Journal of South American Earth Sciences 71, 235-247. http://doi.org/10.1016/j.jsames.2016.08.001

Audemard, F.E., Audemard, F.A. 2002. Structure of the Mérida Andes, Venezuela: relations with the South America-Caribbean geodynamic interaction. Tectonophysics 345, 299-327. http:// doi.org/10.1016/S0040-1951(01)00218-9.

Bezada, M. 1989. Geología Glacial del Cuaternario de la región de Santo Domingo -Pueblo Llano-Las Mesitas (Estados Mérida y Trujillo). PhD. Sc Thesis. Instituto Venezolano de Investigaciones Científicas, Venezuela, $245 \mathrm{pp}$.

Blunier, T., Chappellaz, J., Schwander, J., Dallenbach, A., Stauffer, B., Stocker, T.F., Raynaud, D., Jouzel, J., Clausen, H.B., Hammer, C.U., Johnsen, S.J. 1998. Asynchrony of Antarctic and Greenland climate change during the last glacial period. Nature 394, 739-743. http://doi. org/10.1038/29447.

Braun, C., Bezada, M. 2013. The history and disappearance of glaciers in Venezuela. Journal of Latin American Geography 12, 85-124. http://jstor.org/stable/24394855.

Carcaillet, J., Angel, I., Carrillo, E., Audemard, F.A., Beck, C. 2013. Timing of the last deglaciation in the Sierra Nevada of the Mérida Andes, Venezuela. Quaternary Research 80 (3), 482-494. http://doi.org/10.1016/j.yqres.2013.08.001.

Carrillo, E., Beck, C., Audemard, F.A., Moreno, M., Ollarves, R. 2008. Disentangling Late Quaternary climatic and seismo-tectonic controls on Lake Mucubají sedimentation (Mérida Andes, Venezuela). Palaeogeography, Palaeoclimatology, Palaeoecology 259, 284-300. http://doi.org/10.1016/j.palaeo.2007.10.012.

Clapperton, C.M. 1986. Glacial geomorphology, Quaternary glacial sequence and paleoclimatic inferences in the Ecuadorian Andes. In: V. Gardiner (Ed.), International Geomorphology, Part II. Wiley, London, pp. 843-870.

Clapperton, CM. 1987. Maximal extent of late Wisconsin glaciation in the Ecuadorian Andes. Quaternary of South America and Antarctic Peninsula 5, 165-179.

Clapperton, C.M. 1990. Glacial and Volcanic Geomorphology of the Chimborazo-Carihuairazo Massif, Ecuadorian Andes.Earth and Environmental Science Transactions of the Royal Society of Edinburgh 81, 91-116. http://doi.org/10.1017/S0263593300005174.

Clapperton, C. 1993. Quaternary Geology and Geomorphology of South America. Elsevier, Amsterdam, 779 pp. http://doi.org/10.1016/0169-555X (95)90014-K.

Clapperton, C.M. 2000. Interhemispheric synchronicityof Marine Oxygen Isotope Stage 2 glacier fluctuations along the American cordilleras transect. Journal of Quaternary Science $15,435-468$.

Clapperton, C.M., McEwan, C. 1985. Late Quaternary moraines in the Chimborazo Area, Ecuador. Arctic and Alpine Research 17, 135-142. http://doi.org/10.2307/1550843.

Clapperton, C.M., Hall, M., Mothes, P., Hole, M.J., Helmens, K.F., Kuhry, P., Gemmell, A.M.D. 1997. A Younger Dryas Icecap in the Equatorial Andes. Quaternary Research 47, 13-28. http://doi.org/10.1006/qres.1996.1861. 
CLIMAP Project Members 1976. The surface of the ice-age earth. Science 191 (4232), 1131-1137.

CLIMAP Project Members 1981. Seasonal Reconstruction of the Earth's Surface at the Last Glacial Maximum.

Coronato, A., Rabassa, J. 2007. Late Quaternary in South America. Encyclopedia of Quaternary Science, 1101-1108.

Dirszowsky, R.W., Mahaney, W.C., Hodder, K.R., Milner, M.W., Kalm, V., Bezada, M., Beukens, R.P. 2005.Lithostratigraphy of the Mérida (Wisconsinan) glaciation and Pedregal interstade, Mérida Andes, northwestern Venezuela. Journal of South American Earth Sciences 19, 525 536. http://doi.org/10.1016/j.jsames.2005.07.001.

Giegengack, R., Grauch, R.I. 1975. Quaternary geology of the central Andes, Venezuela: a preliminary assessment. Boletín de Geología, Publ. Especial Venez. 7 (1), 241-283.

González, O. 1995. Comparación de la geología glacial del Cuaternario de las quebradas Mucuchache, Saisay y Muchuruao (Andes Centrales Venezolanos). Estado Mérida. MSc., tesis inédita. Universidad Pedagógica Experimental Libertador-Instituto Pedagógico de Caracas, 245 pp.

González, O., Bezada, M. 2001. Pedología y cronología relativa de los depósitos cuaternarios en tres cuencas de los Andes centrales venezolanos (Estado Mérida). Acta Científica Venezolana $52,210-219$.

Guzmán, O. 2013. Timing and dynamics of river terraces formation in moderate uplifted ranges: the example of Venezuela and Albania. Ph.D. Thesis, Universite de Grenoble, France, 269 pp.

Guzmán, O., Vassallo, R., Audemard, F., Mugnier, J.L., Oropeza, J., Yepez, S., Carcaillet, J., Alvarado, M., Carrillo, E. 2013. ${ }^{10}$ Be dating of river terraces of Santo Domingo River, on Southeastern flank of the Mérida Andes, Venezuela: Tectonic and climatic implications. Journal of South American Earth Sciences 48, 85-96. http://doi.org/10.1016/j.jsames.2013.09.004.

Hansen, B.C.S., Rodbell, D.T., Seltzer, G.O., León, B., Young, K.R., Abbott, M. 2003. Late glacial and Holocene vegetational history from two sites in the western Cordillera of southwestern Ecuador. Palaeogeography, Palaeoclimatology, Palaeoecology 194, 79-108. http://doi. org/10.1016/S0031-0182 (03)00272-4.

Helmens, K.F., Kuhry, P., Rutter, N.W., Van der Borg, K., De Jong, A.F.M. 1996. Warming at 18,000 yr B.P. in the Tropical Andes. Quaternary Research 45, 289-299. http://doi.org/10.1006/ qres.1996.0030.

Heine, K. 1995. Late Quaternary glacier advances in the Ecuadorian Andes: a preliminary report. In: J. Rabassa, M. Salemme (Eds.), Quaternary of South America and Antarctic Peninsula. A.A. Balkema, Rotterdam, pp. 1-22.

Heine, K., Heine, J.T. 1996. Late glacial climatic fluctuations in Ecuador: glacier retreat during younger dryas time. Artic and Alpine Research 28, 496-501. http://doi.org/10.2307/1551860.

Helmens, K.F., Barendregt, R.W., Enkin, R.J., Bakker, J., Andriessen, P.A.M. 1997a. Magnetic polarity and fission-trackchronology of a Late Pliocene-Pleistocene paleoclimatic proxy record in the Tropical Andes. Quaternary Research 48, 15-28. http://doi.org/10.1016/ qres.1997.1886.

Helmens, K.F., Rutter, N.W., Kuhry, P. 1997b. Glacier fluctuations in the Eastern Andes of Colombia (South-America) during the last 45,000 radiocarbon years. Quaternary International 38 (39), 39-48. http://doi.org/10.1016/S1040-6182 (96)00021-3.

Helmens, K.F. 1988. Late Pleistocene glacial sequence in the area of the high plain of Bogotá (Eastern Cordillera, Colombia). Palaeogeography, Palaeoclimatology, Palaeoecology 67, 263-283. http://doi.org/10.1016/0031-0182 (88)90156-3.

Helmens, K.F. 1990. Neogene-Quaternary Geology of the High Plain of Bogotá, Eastern Cordillera, Colombia. Stratigraphy, Paleoenvironments and Landscape Evolution. Dissertationes Botanicae, vol. 163, 202 pp., J. Cramer, Berlin-Stuttgart.

Helmens, K.F. 2004. The Quaternary glacial record of the Colombian Andes. In: J. Ehlers, P.L. Gibbard (Eds.), Quaternary Glaciations-Extent and Chronology, Part III: South America, Asia, Africa, Australasia, Antarctica. Elsevier, Amsterdam, pp. 115-134. 
Helmens, K. F. 2011. Quaternary Glaciations of Colombia. In: J. Ehlers, P.L. Gibbard, P.D. Hughes (Eds.), Quaternary Glaciations-Extent and Chronology, Vol 15. Elsevier, Amsterdam, pp. 815-834.

Helmens, K.F., Kuhry, P. 1995. Glacier fluctuations and vegetation change associated with Late Quaternary climatic oscillations in the Andes near Bogotá, Colombia. Quaternary of South America and Antarctica Peninsula 9, 117-140.

Helmens, K.F., Barendregt, R.W., Enkin, R.J., Bakker, J., Andriessen, P.A.M. 1997a. Magnetic polarity and fission track-chronology of a Late Pliocene-Pleistocene paleoclimatic proxy record in the Tropical Andes. Quaternary Research 48, 15-28. http://doi.org/10.1006/ qres.1997.1886.

Hooghiemstra, H., Ran, E.T.H. 1994. Late Pliocene-Pleistocene high resolution pollen sequence of Colombia: an overview of climatic change. Quaternary International 21, 63-80. http://doi. org/10.1016/1040-6182 (94)90021-3.

Hooghiemstra, H., Melice, J.L., Berger, A., Shackleton, N.J. 1993. Frequency spectra and paleoclimatic variability of the high-resolution 30-1450 ka Funza I pollen record (Eastern Cordillera, Colombia). Quaternary Science Reviews 12, 141-156.

Hoyos-Patiño, F. 1998. Glaciers of South-America-Glaciers of Colombia. In: R.S. Williams Jr., J.G. Ferrigno (Eds.), Satellite Image Atlas of Glaciers of the World. U.S. Geological Survey Professional Paper 1386-I, pp. I11-I30.

Iversen, J. 1954. The Late-glacial Flora of Denmark and its Relation to Climate and Soil. In: Danmarks Geologiske Undersøgelser, Række II, 80.

Jahn, A. 1925. Observaciones glaciológicas en los Andes Venezolanos. Cultura Venezolana 64, 265-280.

Jomelli, V., Favier, V., Rabatel, A., Brunstein, D., Hoffmann, G., Francou, B. 2009. Fluctuations of glaciers in the tropical Andes over the last millennium and palaeoclimatic implications: A review. Palaeogeography, Palaeoclimatology, Palaeoecology 281, 269-282. http://doi. org/10.1016/j.palaeo.2008.10.033.

La Frenierre, J., In Huh, K., Mark, B.G. 2011. Ecuador, Perú and Bolivia. In: J. Ehlers, P.L. Gibbard, P.D. Hughes (Eds.), Quaternary Glaciations-Extent and Chronology, Vol 15. Elsevier, Amsterdam, pp. 773-802.

Kalm, V., Mahaney, W.C. 2011.Late Quaternary Glaciation in the Venezuelan (Mérida) Andes. Developments in Quaternary Science 15, 835-841.

Kelly, M.A., Lowell T.V., Applegate, P.J., Phillips, F. M., Schaefer, J. M., Smith, C. A., Kim, H., Leonard, K.C. 2013. A locally calibrated, late glacial ${ }^{10} \mathrm{Be}$ production rate from low-latitude, high-altitude site in the Peruvian Andes. Quaternary Geochronology 26, 70-85. http://doi. org/10.1016/j.quageo.2013.10.007.

Kohn, B., Shagam, R., Banks, P., Burkley, L. 1984. Mesozoic-Pleistocene fission track ages on rocks of the Venezuelan Andes and their tectonic implications. Geological Society of America Memoir 162, 365-384.

Kuhry, P., Helmens, K.F. 1990. Neogene-Quaternary biostratigraphy and paleoenvironments. In: K.F. Helmens (Ed.), Neogene-Quaternary Geology of the High Plain of Bogotá, Eastern Cordillera, Colombia (Stratigraphy, Paleoenvironments and Landscape Evolution). Dissertationes Botanicae 163, J. Cramer, Berlin-Stuttgart, pp. 89-132.

Kuhry, P., Hooghiemstra, H., Van Geel, B., Van der Hammen, T. 1993. The El Abra stadial in the Eastern Cordillera of Colombia (South America). Quaternary Science Reviews 12, 333-343. http://doi.org/10.1016/0277-3791 (93)90041-J.

Mahaney, W.C., Milner, M.W., Voros, J. Kalm, V., Hütt, G., Bezada, M., Hancock, R.G.V., Autreiter, S. 2000. Stratotype for the Mérida Glaciation at Pueblo Llano in the Northern Venezuela Andes. Journal of South American Earth Sciences 13, 761-774. http://doi. org/10.1016/S0895-9811(00)00054-7. 
Mahaney, W.C., Russell S.E., Milner, M.W., Kalm V., Bezada M., Hancock, R.G.V., Beukens R.P. 2001. Paleopedology of Middle Wisconsin/Weichselian paleosols in the Mérida Andes, Venezuela. Geoderma 104, 215-237. http://doi.org/10.1016/S0016-7061 (01)00082-9.

Mahaney, W.C., Dirszowsky, R. W., Milner, M. W., Harmsen, R., Finkelstein, S. A., Kalm, V., Bezada, M., Hancock, R.G.V. 2007. Soil stratigraphy and plant-soil interactions on a Late Glacial-Holocene fluvial terrace sequence, Sierra Nevada National Park, northern Venezuelan Andes. Journal of South American Earth Sciences 23, 46-60. http://doi.org/10.1016/j. jsames.2006.09.020.

Mahaney, W.C., Milner, M.W., Kalm, V. Dirszowsky, R.W., Hancock, R.G.V., Beukens, R.P. 2008. Evidence for a Younger Dryas glacial advance in the Andes of northwestern Venezuela. Geomorphology 96, 199-211. http://doi.org/10.1016/j.geomorph.2007.08.002.

Mahaney, W.C., Kalm, V., Menzies, J., Hancock, R.V.V., Milner, M.W. 2010a. Reconstruction of the pre-Merida glaciation, northwestern Venezuelan Andes. Sedimentary Geology 230, 10 20. http://doi.org/10.1016/j.sedgeo.2010.06.016.

Mahaney, W.C., Kalm, V., Menzies, J., Milner, M.W. 2010b. Reconstruction of the Early Mérida, pre-LGM glaciation with comparison to Late Glacial Maximum till, northwestern Venezuelan Andes. Sedimentary Geology 226, 29-41. http://doi.org/10.1016/j.sedgeo.2010.02.004.

Pindell, J.L.,Higgs, R., Dewey, J.F. 1998. Cenozoic palinspastic reconstruction, paleogeographic evolution and hydrocarbon setting of the northern margin of South America. Society of Sedimentary Geology, Special Publ. 58, 4586.

Rodbell, D.T., Bagnato S., Nebolini, J.C., Seltzer, G.O., Abbott, M.B. 2002. A late glacial Holocene tephrochronology for glacial lakes in southern Ecuador. Quaternary Research 57, 343-354. http://doi.org/10.1006/qres.2002.2324.

Rodbell, D.T., Smith, J.A., Mark, B.G. 2009. Glaciation in the Andes during the Lateglacial and Holocene. Quaternary Science Reviews 28, 2165-2212. http://doi.org/10.1016/j. quascirev.2009.03.012.

Rull, V. 1998. Palaeoecology of pleniglacial sediments from the Venezuelan Andes.Palynological record of El Caballo stadial, sedimentation rates and glacier retreat. Review of Palaeobotany and Palynology 99, 95-114. http://doi.org/10.1016/S0034-6667 (97)00043-2.

Rull, V., Stansell, N.D., Montoya, E., Bezada, M., Abbott, M.B. 2010. Palynological signal of the Younger Dryas in the tropical Venezuelan Andes. Quaternary Science Reviews 29, 30453056. http://doi.org/10.1016/j.quascirev.2010.07.012.

Shackleton, N.J., Lamb, H.H., Worssam, J.M., Hodgson, J.M., Lord, A.R., Shotton, F.W., Schove, D.J., Cooper, L.H.N. 1977. The oxygen isotope stratigraphic record of the Late Pleistocene (and discussion). Philosophical Transactions of the Royal Society of London B 280, 169-182.

Shakun, J.D., Carlson, A.E. 2010. A global perspective on Last Glacial Maximum to Holocene climate change. Quaternary Science Reviews 29, 1801-1816. http://doi.org/10.1016/j. quascirev.2010.03.016.

Schubert, C. 1974. Late Pleistocene Merida Glaciation, Venezuelan Andes. Boreas 3, 147-151. http://doi.org/10.1111/j.1502-3885.1974.tb00673.x.

Schubert, C. 1979. Glacial sediments in the Venezuelan Andes. In: C. Schluchter (Ed.), Moraines and Varves. Origin, Genesis, Classification. Proceedings of an INQUA Symposium on Genesis and Lithology of Quaternary Deposits, Balkema, Zurich, pp. 43-49.

Schubert, C. 1984. The Pleistocene and recent extent of the glaciers of the Sierra Nevada de Mérida, Venezuela. Erdwissenshaftliche Forshung 18, 269-278.

Schubert, C., Rinaldi, M. 1987. Nuevos datos sobre la cronología del estadio tardío de la Glaciación Mérida, Andes Venezolanos. Acta Científica Venezolana 38, 135-136.

Schubert, C., Clapperton, C.M. 1990. Quaternary Glaciations in the northern Andes (Venezuela, Colombia and Ecuador). Quaternary Science Reviews 9 (2-3), 123-135. http://doi. org/10.1016/0277-3791 (90)90014-2. 
Schubert, C., Vivas, L. 1993. El Cuaternario de la Cordillera de Mérida, Andes Venezolanos. Universidad de Los Andes / Fundación POLAR, Mérida, Venezuela, 345 pp.

Seltzer, G. O., Rodbell D.T., Abbott M. 1995. Andean glacial lakes and climate variability since the last glacial maximum. Bulletin de l'Institut Français d'Études Andines 24, 539-549.

Sievers, W. 1885. Über Schneeverhältnisse in der Cordillere Venezuelas. Jahresbericht der Geographischen Gesellschaft in München 10, 54-57.

Smith, J.A, Mark, B.G. Rodbell, D.T. 2008. The timing and magnitude of mountain glaciation in the tropical Andes. Journal of Quaternary Science 23 (6-7), 609-634. http://doi.org/10.1002/ jqs. 1224 .

Stansell, N.D., Abbott, M.B., Polissar, P.J., Wolfe, A.P., Bezada, M., Rull, V. 2005. Late Quaternary deglacial history of the Mérida Andes, Venezuela. Journal of Quaternary Science 20 (7-8), 801-812. http://doi.org/10.1002/jqs.973.

Stansell, N.D., Polissar, P.J., Abbott, M.B. 2007. Last glacial maximum equilibrium-line altitude and paleo-temperature reconstructions for the Cordillera de Mérida, Venezuelan Andes. Quaternary Research 67, 115-127. http://doi.org/10.1016/j.yqres.2006.07.005.

Stansell, N.D., Abbott, M.B., Rull, V., Rodbell, D.T., Bezada, M., Montoya, E. 2010, Abrupt Younger Dryas cooling in the northern tropics recorded in lake sediments from the Venezuelan Andes. Earth and Planetary Science Letters 293, 154-163. http://doi. org/10.1016/j.epsl.2010.02.040.

Thouret, J.C., van der Hammen, T., Salomons, B. 1996. Paleoenvironmental changes and stades of the last 50,000 years in the Cordillera Central, Colombia. Quaternary Research 46, 1-18. http://doi.org/10.1006/qres.1996.0039.

Tricart, J. 1966. Geomorfología del área de Mucuchíes. Revista de Geografía Universidad de los Andes 7, 31-42.

van der Hammen, T., Werner, J.H., Van Dommelen, H. 1973. Palynological record of the upheaval of the Northern Andes: a study of the Pliocene and Lower Quaternary of the Colombian Eastern Cordillera and the early evolution of its High-Andean biota. Review of Palaeobotany and Palynology 16, 1-122. http://doi.org/10.1016/0034-6667 (73)90031-6.

van der Hammen, T., Barelds, J., De Jong, H., De Veer, A.A. 1980. Glacial sequence and environmental history in the Sierra Nevada del Cocuy (Colombia). Palaeogeography, Palaeoclimatology, Palaeoecology 32, 247-340. http://doi.org/10.1016/0031-0182 (80)90043-7.

van der Hammen, T. 1981. Glaciares y glaciaciones en el Cuaternario de Colombia: paleoecología y estratigrafía. Revista CIAF 6, 635-638.

van Geel, B., van der Hammen, T. 1973. Upper Quaternary vegetational and climatic sequence of the Fúquene area (Eastern Cordillera, Colombia). Palaeogeography, Palaeoclimatology, Palaeoecology 14, 9-55, 73-92. http://doi.org/10.1016/0031-0182 (73)90064-3.

van't Veer, R., Islebe, G.A., Hooghiemstra, H. 2000. Climatic change during the Younger Dryas chron in northern South America: a test of the evidence. Quaternary Science Reviews 19, 1821-1835. http://doi.org/10.1016/S0277-3791(00)00093-7.

Vivas, L. 1974. Estudio geomorfológico de la cuenca superior de la quebrada Tuñame. Revista de Geografía Universidad de los Andes 11, 69-112.

Wesnousky, S.G., Aranguren, R., Rengifo, M., Owen, L.A., Caffee, M.W., Krishna Murari, M., Pérez, O.J. 2012. Toward quantifying geomorphic rates of crustal displacement, landscape development, and the age of glaciation in the Venezuelan Andes. Geomorphology 141-142, 99-113. http://doi.org/10.1016/j.geomorph.2011.12.028.

Wijninga, V.M. 1996. Paleobotany and palynology of Neogene sediments from the high plain of Bogotá (Colombia)-evolution of the Andean flora from a paleoecological perspective. $\mathrm{PhD}$ thesis, University of Amsterdam, 370 pp. 